\title{
Human corneal stromal tissue concentration after consecutive doses of topically applied $3.3 \%$ vancomycin
}

\author{
M Cahane, G J Ben Simon, I S Barequet, A Grinbaum, L Diamanstein-Weiss, O Goller, \\ E Rubinstein, I Avni
}

Br J Ophthalmol 2004;88:22-24

\begin{abstract}
Aims: To evaluate vancomycin penetration into human corneal stromal tissue in patients treated with topical vancomycin eyedrops before penetrating keratoplasty (PKP). Methods: Twenty four patients who underwent PKP, seven patients with keratoconus (group 1) and 17 patients with corneal scar or corneal decompensation (group 2). All patients received topical application of vancomycin eyedrops (concentration: $33 \mathrm{mg} / \mathrm{ml}$ ) 10, 3, 2, 1 hour, and 15 minutes before the operation. Corneal cumulative vancomycin levels were assessed by bioassay.

Results: Mean vancomycin corneal stromal tissue concentration was 46.7 (SE 4.11 ) $\mu \mathrm{g} / \mathrm{g}$ tissue. This value was four to 20 -fold in excess of the MIC90 of vancomycin in Staphylococcus aureus $(2-10 \mu \mathrm{g} / \mathrm{ml})$.

Conclusions: Vancomycin reached high corneal tissue concentrations that significantly exceeded the MIC90 (2-10 $\mu \mathrm{g} /$ $\mathrm{ml}$ ) for most key Gram positive corneal pathogens. The ratio of vancomycin stromal concentration to protein concentration was statistically higher in group 2 (non-keratoconus).
\end{abstract}

M anagement of bacterial corneal infections usually involves frequent administration of antimicrobial eyedrops. Staphylococcus epidermidis and Staphylococcus aureus are among the most commonly isolated bacteria in cultures from bacterial keratitis. ${ }^{1-4}$

Vancomycin is a highly effective antibiotic treatment for Gram positive organisms, and is frequently prescribed for Severe corneal infections. Because of the increasing incidence of bacterial keratitis caused by methicillin resistant $S$ aureus, (MRSA) and methicillin resistant $S$ epidermidis (MRSE), vancomycin has become one of the most extensively used antibiotic treatments. ${ }^{56}$

Corneal penetration of various antibiotics has already been tested in vitro and in vivo. ${ }^{13}{ }^{7-9}$ To the best of our knowledge, levels of vancomycin in human corneas have never been measured. The purpose of this study was to measure corneal stromal tissue vancomycin levels in patients receiving topical vancomycin before penetrating keratoplasty (PKP). The study also evaluated the effect of vancomycin treatment on bacterial cultures obtained from the conjunctival sac, before and after vancomycin topical administration.

\section{PATIENTS AND METHODS}

A group of 24 patients ( 14 males, 10 females, mean (SD) age 59 (20.9), range 19-79 years) received topical vancomycin eyedrops $(33 \mathrm{mg} / \mathrm{ml}) 10$ hours, three hours, two hours, one hour and 15 minutes before PKP (one eyedrop each time in the operative eye). Vancomycin drops were prepared by mixing vancomycin in normal saline $(0.9 \%)$. The study protocol was approved by the Human Subjects Committee of our institution, and followed the tenets of the Helsinki Declaration. Informed consent was obtained from all patients after explanation of the nature and possible consequences of the study.

Indications for PKP included keratoconus $(n=7)$, bullous keratopathy, or corneal decompensation $(n=11)$, graft rejection $(n=3)$, leukoma cornea $(n=2)$, and Fuchs' corneal dystrophy $(\mathrm{n}=1)$. The patients were divided into two groups according to the indication for keratoplasty: group 1 with keratoconus $(\mathrm{n}=7)$ and intact epithelium, and group 2 that comprised all the other patients. None of the patients in group 2 had corneal erosion. All but two patients (those with leukoma cornea) had focal punctate fluorescein staining; the staining pattern was not graded clinically.

All patients received one vancomycin eyedrop $(33 \mathrm{mg} / \mathrm{ml})$ in the operative eye 10 hours, three hours, two hours, one hour, and 15 minutes before the operation. A control group comprising four patients (two males, two females; mean (SD) age 57.25 (17.46); range $40-78$ years) did not receive any antibiotic treatment before surgery. Indications for PKP in this group included rejected graft $(n=3)$, and Fuchs' corneal dystrophy $(\mathrm{n}=1)$.

Before trephination, the surface of the cornea and the fornices were thoroughly irrigated with saline solution and cleaned with a cellulose sponge to remove any antibiotic residues. The epithelial layer was then removed from the centre of the cornea with the help of a beaver knife. Excised buttons were weighed and placed in a sterile container. All samples were stored at $-80^{\circ} \mathrm{C}$ before laboratory investigation.

Bacterial cultures were obtained from the conjunctival cul de sac before and after treatment with vancomycin from the treated eye only.

\section{LABORATORY METHODS}

Corneal specimens were thawed, and ground to a fine powder. The samples were then diluted with normal saline, and enzymatically digested by trypsin $(0.2 \mathrm{ml}, 25 \mathrm{mg} / \mathrm{ml})$, and collagenase $(0.2 \mathrm{ml}, 10 \mathrm{mg} / \mathrm{ml})$. The solvent was incubated for one hour at $37^{\circ} \mathrm{C}$, and protein content within the solution was measured by the Bred-ford method (BioRad, USA, standard assay protocol).

Vancomycin cumulative concentrations were determined by a bioassay technique using B subtilis ATCC 6633 on antibiotic medium No. 5 (Difco, Detroit, MI, USA) that yielded a coefficient of variation of $\pm 11 \%$ for vancomycin concentrations of $0.1-75 \mu \mathrm{g} / \mathrm{ml}$. Statistical analysis was performed using the SPSS program.

\section{RESULTS}

Vancomycin corneal tissue concentration in the study group was 46.70 (SEM 4.11 ) $\mu \mathrm{g} / \mathrm{g}$ corneal tissue (or $\mu \mathrm{g} / \mathrm{ml}$, as more than $90 \%$ of the cornea tissue is composed of water). This value considerably exceeded the $\mathrm{MIC}_{90}$ of vancomycin to Staphylococcus aureus which is less than $4 \mu \mathrm{g} / \mathrm{ml} .^{9-10}$ No 


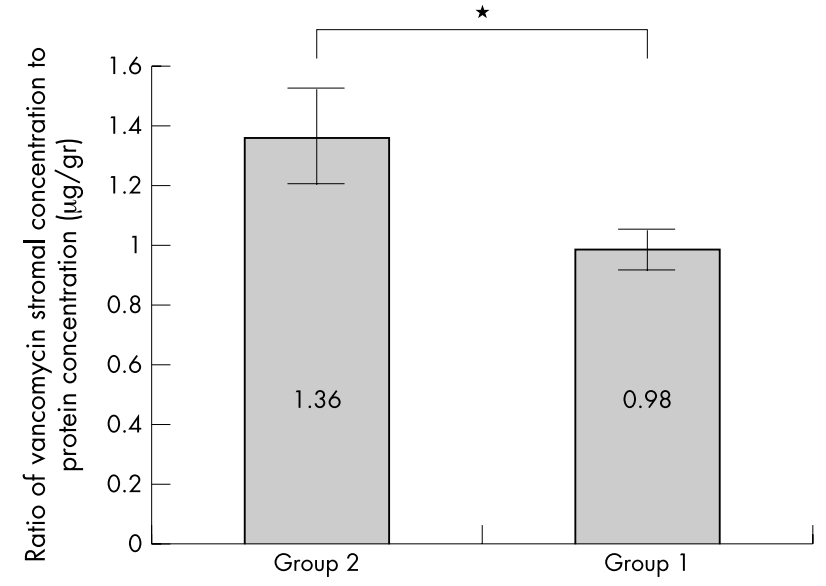

Figure 1 The ratio of vancomycin stromal concentration to protein concentration in group 1 (keratoconus) and in group 2 (nonkeratoconus). ${ }^{*} \mathrm{p}<0.05$.

difference was found in vancomycin corneal concentrations between two groups.

The mean vancomycin concentration in relation to corneal protein content was $1.25(0.12) \mu \mathrm{g} / \mathrm{g}$, but was found to be statistically significantly higher in group $2(1.36(0.16) \mu \mathrm{g} / \mathrm{g})$ than in group l $(0.98(0.07) \mu \mathrm{g} / \mathrm{g}),(\mathrm{p}=0.036,95 \% \mathrm{CI}-0.75$ to -0.03$)$.

The levels of vancomycin in the control group were not detectable by bioassay (marked as 0). Data from study patients are summarised in the table.

In 23 patients $(82 \%)$, bacterial cultures from the conjunctival cul de sac were sterile after administration of vancomycin. Eight of these patients had positive cultures before treatment. Two patients had positive cultures before and after administration of topical vancomycin (one with $S$ aureus coagulase negative, and the other patient showed growth of sporelacerus). None of the patients showed any sign of clinical infection after surgery.

\section{DISCUSSION}

Vancomycin is an antimicrobial glycopeptide active against almost all clinically significant Gram positive cocci. ${ }^{1}$ The increase in antimicrobial resistance to Gram positive cocci, particularly the appearance of MRSA and MRSE, has popularised vancomycin as an important alternative treatment. ${ }^{1-3} 81112$

Vancomycin, when tested as an additive antibiotic in corneal storage media, proved to be safe at a concentration of $200 \mu \mathrm{g} / \mathrm{ml}$, and did not induce any corneal endothelial cell damage. Vancomycin was found to penetrate well, and even appeared to concentrate in the corneal button. ${ }^{10}$

Vancomycin concentrations in human aqueous humour after different routes of administration were assessed by several investigators. ${ }^{13}{ }^{14}$ Souli et $a l^{13}$ evaluated the concentration of vancomycin after intravenous and subconjunctival injection and found that only the latter achieved therapeutic concentrations of the drug in the aqueous. Huerva et $a l^{14}$ have shown concentrations of $0.52 \mu \mathrm{g} / \mathrm{ml}$ of vancomycin for the first two hours after topical administration decreasing to $0.15 \mu \mathrm{g} / \mathrm{ml}$ four hours after last administration and undetectable thereafter. These concentrations are lower than achieved in corneal stroma in the present study because aqueous is constantly diluting vancomycin in the anterior chamber.

In all our patients, concentrations of vancomycin corneal stromal exceeded the $\mathrm{MIC}_{90}(2-10 \mu \mathrm{g} / \mathrm{ml})$ for most key corneal pathogens. No difference in corneal vancomycin concentration was found between group 1 (keratoconus) and group 2 (other medical indications for PKP), but vancomycin concentration in relation to protein was statistically significantly higher in group 2 (non-keratoconus). Keratoconus corneas usually have an intact epithelium, thus vancomycin penetration may be lower than in other corneal diseases in which the corneal epithelial layer is damaged (such as failed graft or corneal decompensation).

We think that the corneas in the group 1 patients with intact epithelium (keratoconus patients) may resemble normal human corneas; thus, penetration of vancomycin

\begin{tabular}{|c|c|c|c|c|c|c|c|c|}
\hline No & Sex & Birth year & Diagnosis* & $\begin{array}{l}\text { Corneal } \\
\text { weight (gr) }\end{array}$ & $\begin{array}{l}\text { Vanco** } \\
\mu \mathrm{g} / \mathrm{ml}\end{array}$ & $\begin{array}{l}\text { Vanco per } \\
\text { tissue } \\
(\mu \mathrm{g} / \mathrm{g})\end{array}$ & $\begin{array}{l}\text { Protein } \\
\text { (mg/ml) }\end{array}$ & $\begin{array}{l}\text { Vanco per } \\
\text { protein } \\
(\mu \mathrm{g} / \mathrm{ml})\end{array}$ \\
\hline 1 & M & 1927 & Leukoma & 0.0377 & 1.70 & 90.19 & 0.680 & 2.50 \\
\hline 2 & M & 1940 & Stromal oedema & 0.0377 & 0.59 & 31.30 & 0.730 & 0.81 \\
\hline 3 & M & 1971 & Keratoconus & 0.0403 & 1.10 & 54.59 & 0.810 & 1.36 \\
\hline 4 & M & 1968 & Keratoconus & 0.0336 & 0.80 & 47.62 & 0.880 & 0.91 \\
\hline 5 & $\mathrm{~F}$ & 1976 & Keratoconus & 0.0384 & 0.65 & 33.85 & 0.665 & 0.98 \\
\hline 6 & M & 1927 & Stromal oedema & 0.0366 & 0.98 & 53.55 & 0.530 & 1.85 \\
\hline 7 & $\mathrm{~F}$ & 1929 & Stromal oedema & 0.0421 & 0.60 & 28.50 & 0.590 & 1.02 \\
\hline 8 & $\mathrm{~F}$ & 1921 & Stromal oedema & 0.0362 & 1.23 & 67.68 & 0.475 & 2.58 \\
\hline 9 & $\mathrm{~F}$ & 1924 & Stromal oedema & 0.0429 & 1.04 & 48.48 & 0.600 & 1.73 \\
\hline 10 & $\mathrm{~F}$ & 1921 & Stromal oedema & 0.0511 & 1.70 & 66.54 & 0.886 & 1.92 \\
\hline 11 & $\mathrm{~F}$ & 1921 & Stromal oedema & 0.0369 & 0.64 & 34.69 & 0.722 & 0.89 \\
\hline 12 & M & 1920 & Stromal oedema & 0.0239 & 0.88 & 73.64 & 0.781 & 1.13 \\
\hline 13 & $\mathrm{~F}$ & 1922 & Stromal oedema & 0.0475 & 1.70 & 71.58 & 0.866 & 1.96 \\
\hline 14 & M & 1949 & Keratoconus & 0.0399 & 0.60 & 30.08 & 0.828 & 0.72 \\
\hline 15 & M & 1942 & Stromal oedema & 0.0393 & 0.88 & 44.78 & 0.887 & 0.99 \\
\hline 16 & $\mathrm{~F}$ & 1925 & Fuchs' dystrophy & 0.0340 & 0.46 & 27.06 & 0.991 & 0.46 \\
\hline 17 & M & 1930 & Failed graft & 0.0389 & 1.70 & 87.40 & 0.900 & 1.89 \\
\hline 18 & M & 1941 & Failed graft & 0.0416 & 0.76 & 36.54 & 0.727 & 1.05 \\
\hline 19 & M & 1930 & Failed graft & 0.0396 & 0.64 & 32.32 & 0.787 & 0.81 \\
\hline 20 & M & 1926 & Leukoma & 0.0615 & 0.46 & 14.96 & 0.557 & 0.83 \\
\hline 21 & $\mathrm{~F}$ & 1974 & Keratoconus & 0.0279 & 0.62 & 44.44 & 0.635 & 0.98 \\
\hline 22 & $\mathrm{~F}$ & 1925 & Stromal oedema & 0.0307 & 0.47 & 30.62 & 0.600 & 0.78 \\
\hline 23 & M & 1968 & Keratoconus & 0.0322 & 0.70 & 43.48 & 0.720 & 0.97 \\
\hline 24 & M & 1980 & Keratoconus & 0.0451 & 0.61 & 27.05 & 0.670 & 0.91 \\
\hline
\end{tabular}


into the stroma of normal corneas may be of similar magnitude. This was not examined in our study.

In patients with corneal bacterial infiltrates in which the epithelial layer is damaged, stromal penetration of vancomycin could be even higher and resemble that of group 2 . When ruling out the effect of corneal oedema by measuring vancomycin concentrations related to protein content, we found that penetration of vancomycin was better in group 2 than in group 1.

In summary, in this study high concentrations of vancomycin were measured in human corneal stroma after topical administration. These levels exceeded the $\mathrm{MIC}_{90}$ of vancomycin to common corneal pathogens, and thus are of both therapeutic and prophylactic value, supporting the use of vancomycin in the treatment and prevention of corneal infections.

\section{Authors' affiliations}

M Cahane*, G J Ben Simon*, I S Barequet, A Grinbaum,

L Diamanstein-Weiss, O Goller, E Rubinstein, I Avni, Goldschleger Eye Institute, Sheba Medical Center, Ramat Gan, Israel

*These authors contributed equally to the work.

Correspondence to: $\operatorname{Dr}$ G J Ben Simon, Goldschleger Eye Institute, Sheba Medical Center, Ramat Gan, 52621 Israel; guybs@barakonline.net

Accepted for publication 26 May 2003

\section{REFERENCES}

1 Phinney RB, Schwartz SD, Lee DA, et al. Collagen-shield delivery of gentamycin and vancomycin. Arch Ophthalmol 1988;106:1599-1604.

2 Callegan MC, Engel LS, Hill JM, et al. Ciprofloxacin versus tobramycin for the treatment of staphylococcal keratitis. Invest Ophthalmol Vis Sci 1994;35:1033-7.

3 McDermott ML, Tran TD, Cowden JW, et al. Corneal stromal penetration of topical ciprofloxacin in humans. Ophthalmology 1993;100:197-200.

4 Schaefer F, Bruttin O, Zografos L, et al. Bacterial keratitis: a prospective clinical and microbiological study. Br J Ophthamol 2001;85:842-7.

5 Goodman DF, Gottsch JD. Methicillin-resistant staphylococcus epidermidis keratitis treated with vancomycin. Arch Ophthalmol 1988;106:1570-1.

6 Gordon YJ. Perspective: Vancomycin prophylaxis and emerging resistance: Are ophthalmologists the villains? The heroes? Am J Ophthalmol 2001;31:371-6.

7 Barza M, Kane A, Baum J. A collagenase digestion method for bioassay of antibiotics in ocular tissues. Am J Ophthalmol 1978;86:121-8.

8 Price FW Jr, Whitson WE, Collins KS, et al. Corneal tissue levels of topically applied ciprofloxacin. Cornea 1995:152-6.

9 Insler MS, Helm CJ, George WJ. Topical vs systemic gentamycin penetration into the human cornea and aqueous humor. Arch Ophthalmol 1987; 105:922-4.

10 Watanakunakorn C. The antibacterial action of vancomycin. Rev Infect Dis 1981;3(suppl):S210-S15.

11 Lindquist TD, Roth BP, Fritsche TR. Stability and activity of vancomycin in corneal storage media. Cornea 1993; 12:222-7.

12 Smith MA, Sorenson JA, Lowy FD, et al. Treatment of experimental methicillinresistant staphylococcus epidermidis endophthalmitis with intravitreal vancomycin. Ophthalmology 1986;93:1328-35.

13 Souli M, Kopsinis G, Kavouklis E, et al. Vancomycin levels in human aqueous humour after intravenous and subconjunctival administration. Int $J$ Antimicrob Agents $2001 ; 18: 239-43$.

14 Huerva V, Sinues B, del Buey MA, et al. Levels of vancomycin in aqueous humor after topical eye drops administration. J Ocul Pharmacol 1993;9:167-70.

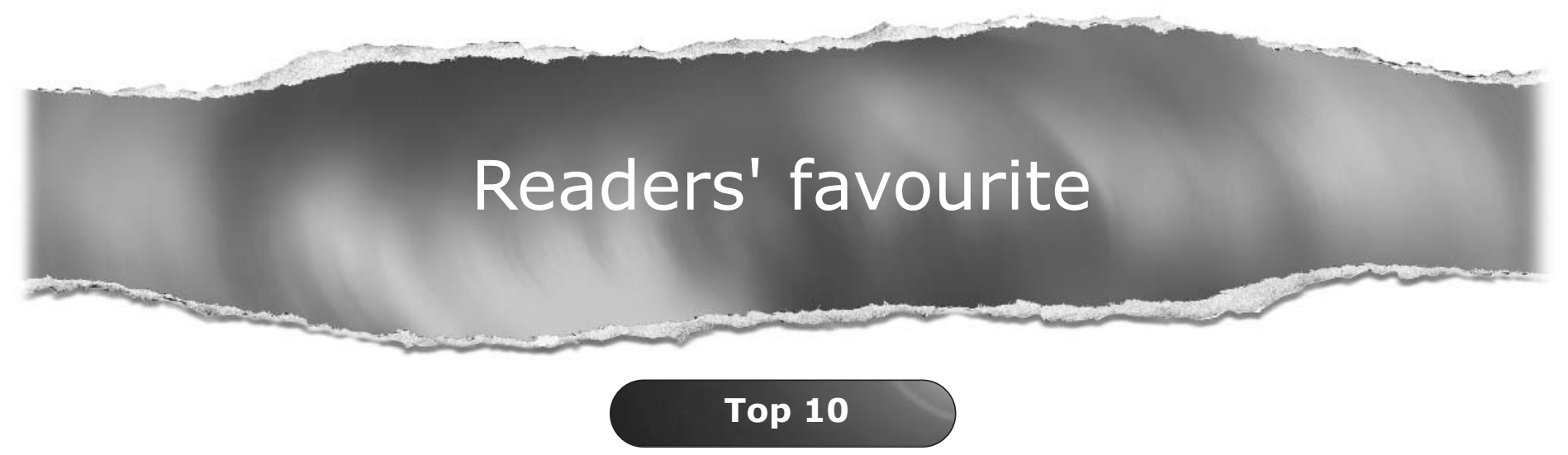

Click on the "Top 10" button on the homepage to see which are the best read articles each month

\section{www.bjophthalmol.com}

